\title{
Effects of the scid mutation on X-ray- induced deletions in the brain and spleen of gpt delta mice
}

\author{
Kenichi Masumura ${ }^{{ }^{*}}$, Fumio Yatagai ${ }^{2}$, Masako Ochiai ${ }^{3,4}$, Hitoshi Nakagama ${ }^{3,5}$ and Takehiko Nohmi ${ }^{*}$ (D)
}

\begin{abstract}
Background: DNA-dependent protein kinase (DNA-PK), consisting of a Ku heterodimer (Ku70/80) and a large catalytic subunit (DNA-PKcs), plays an important role in the repair of DNA double-strand breaks via nonhomologous end-joining (NHEJ) in mammalian cells. Severe combined immunodeficient (scid) mice carry a mutation in the gene encoding DNA-PKcs and are sensitive to ionizing radiation. To examine the roles of DNA-PKcs in the generation of deletion mutations in vivo, we crossed scid mice with gpt delta transgenic mice for detecting mutations.

Results: The scid and wild-type (WT) gpt delta transgenic mice were irradiated with a single X-ray dose of 10 Gy, and $\mathrm{Spi}^{-}$mutant frequencies (MFs) were determined in the brain and spleen 2 days after irradiation. Irradiation with X-rays significantly enhanced Spi ${ }^{-}$MF in both organs in the scid and WT mice. The MFs in the brain of irradiated scid mice were significantly lower than those in WT mice, i.e., $2.9 \pm 1.0 \times 10^{-6}$ versus $5.0 \pm 1.1 \times 10^{-6}(P<0.001)$, respectively. In the spleen, however, both mouse strains exhibited similar MFs, i.e., $4.1 \pm 1.8 \times 10^{-6}$ versus $4.8 \pm 1.4 \times$ $10^{-6}$. Unirradiated scid and WT mice did not exhibit significant differences in MFs in either organ.
\end{abstract}

Conclusions: DNA-PKcs is unessential for the induction of deletion mutations in the spleen, while it plays a role in this in the brain. Therefore, the contribution of DNA-PKcs to NHEJ may be organ-specific.

Keywords: DNA-PKcs, scid mice, Non-homologous end-joining, Spi ${ }^{-}$assay, Deletion, X-irradiation

\section{Introduction}

The repair of DNA double-strand breaks (DSBs) is critical for the maintenance of genomic integrity. In mammalian cells, DSBs are repaired by the homologous recombination and/or the nonhomologous end-joining (NHEJ) pathways [1-3]. However, DSBs induced by ionizing radiation (IR) are mainly repaired through NHEJ pathway. This is particularly true in non-dividing cells and in G1 cells due to the absence of sister chromatids, the preferred substrate for homologous recombination. Although defects in NHEJ result in genomic

\footnotetext{
* Correspondence: masumura@nihs.go.jp; nohmi@nihs.go.jp

'Division of Genetics and Mutagenesis, National Institute of Health Sciences, 3-25-26 Tonomachi, Kawasaki-ku, Kawasaki-shi, Kanagawa 210-9501, Japan Full list of author information is available at the end of the article
}

instability and cancer predisposition, NHEJ often leads to deletion mutations, with or without short length insertions, when DNA ends can't be directly ligated [4]. IR and chemical treatments usually induce modified DSBs with ends that are incompatible for direct ligation. Therefore, NHEJ can be regarded as a double-edged sword; while it prevents cell death and gross chromosome rearrangements, it often induces deletions and insertions during ligation of incompatible ends.

DNA-dependent protein kinase (DNA-PK) consists of three components, the catalytic subunit DNA-PKcs and the heterodimeric Ku70 and Ku80 proteins, and is involved in NHEJ of DNA DSBs and V(D)J recombination [5-9]. In general, when DNA DSBs are induced, Ku70/ 80 proteins bind to the ends and interact with other 
proteins including DNA PKcs and Artemis for endresection, DNA polymerase $\mu$ and $\lambda$ for addition of nucleotides, and the DNA ligase IV complex for ligation of the ends. However, different proteins are recruited to the site of DNA damage to participate in the repair of DSBs each time, depending on the end configurations i.e., blunt ends, 3 ' - or $5^{\prime}$-overhands or ends containing modified bases [10].

The scid (severe combined immune-deficiency) mice bear a naturally occurring mutation in the DNA-PKcs gene that results in an 83-amino acid truncation of the C-terminal end [11-14]. These mice, and cells derived from them, are hypersensitive to IR, display defects in joining of IR-induced DNA DSBs [12, 15], and are defective in coding joint formation during $\mathrm{V}(\mathrm{D}) \mathrm{J}$ recombination $[16,17]$. However, scid cells can form signal joints in $\mathrm{V}(\mathrm{D}) \mathrm{J}$ recombination [18], which involve the joining of the ends created after the excision of intervening DNA during $V(D) J$ recombination and the formation of circular DNA molecules. In contrast, Ku-deficient mice and embryonic stem cells exhibit defects in both coding and signal joint formation [19-22]. Therefore, it appears that DNA-PKcs is only needed to resolve a subset of DSBs and that NHEJ may proceed in a DNA-PKcsindependent, as well as DNA-PKcs-dependent, manner.

We previously developed the gpt delta transgenic mouse for the detection of mutations in vivo [23-25]. In gpt delta mice, about 80 copies of lambda EG10 DNA, which carries red and gam genes, are integrated into each chromosome 17 in a C57BL/6 J background $[26,27]$. A feature of the mutation assay is its ability to efficiently detect certain types of deletions by $\mathrm{Spi}^{-}$ (sensitive to P2 interference) selection, as well as point mutations, i.e., base substitutions and frameshifts, by 6-thioguanine selection $[28,29]$. $\mathrm{Spi}^{-}$selection takes advantage of the restricted growth of the lambda phage in P2 lysogens [30]. Only mutant lambda phages that are deficient in the functions of both red and gam genes can grow well in P2 lysogens and display the $\mathrm{Spi}^{-}$phenotype. Simultaneous inactivation of the two adjacent genes is usually induced by a deletion in the region, or frameshifts that interfere with the translation of both genes. $\mathrm{Spi}^{-}$selection detects deletions ranging from single nucleotide $(-1)$ frameshifts to $10 \mathrm{~kb}$ in size [29]. In this procedure, the lambda EG10 is rescued from the mouse genome by in vitro packaging reactions, and P2 lysogens are infected with the rescued phages to identify $\mathrm{Spi}^{-}$plaque. We have demonstrated that the $\mathrm{Spi}^{-}$mutant frequency (MF) is substantially increased by IR and chemical treatments, and suggested that NHEJ repair plays an important role in the induction of $\mathrm{Spi}^{-}$deletion mutants [28, 31, 32].

Since NHEJ may proceed in DNA PKcs-dependent and independent manners, it may be possible that DNA
PKcs plays a significant role in deletion formation in one organ while it plays only a negligible role in another one. It is reported that MF of unirradiated $\mathrm{Ku} \mathrm{O}^{-/-}$mice is higher than that of WT mice in the spleen while the MFs are similar between two strains of mice in the liver [33]. To examine the possible variation of the roles of DNA PKcs in deletion mutations in mammalian organs, we crossed scid mice with gpt delta mice (hereafter, the offspring from this cross will be referred to as scid mice, and gpt delta mice as wild-type (WT) mice). We irradiated scid and WT mice with X-rays and compared $\mathrm{Spi}^{-}$ MFs in the brain and spleen, which are representative organs with quiescent and proliferating cells, respectively. The results indicated that X-ray irradiation significantly induced deletion mutations in both organs of scid and WT mice. Although scid mice exhibited significantly lower MFs than WT mice in the brain, both mouse strains exhibited similar MFs in the spleen. Possible mechanisms of DNA-PKcs-independent NHEJ of DNA DSBs are discussed.

\section{Materials and methods}

Treatment of animals

C.B-17 scid mice, maintained in CLEA Japan, were crossed with C57BL6/J lambda EG10-homozygous gpt delta mice [26]. The heterozygous F1 mice were mated with the same offspring carrying the scid mutation and lambda EG10 transgene, which resulted in F2 mice. The scid genotype of each experimental animal was confirmed by PCR, according to a previously reported method [13]. The existence of the transgene was also confirmed using a previously reported method [26]. Eleven- to twelve-week-old WT (wt/wt) and scid (scid/ scid) mice were whole-body irradiated with X-rays; a total dose of $10 \mathrm{~Gy}$. X ray-irradiation $(200 \mathrm{kVp}$, SoftexRigaku) was delivered at a dose rate of $1 \mathrm{~Gy}$ per min. Each group consisted of a total of 6-10 male and female mice. The mice were sacrificed 2 days following irradiation. The brain and spleen were collected and quickly frozen in liquid nitrogen and stored at $-80^{\circ} \mathrm{C}$. Genomic DNA was extracted from the organs using the phenol/ chloroform method and lambda EG10 phages were rescued using Transpack ${ }^{\mathrm{R}}$ Packaging Extract (Agilent Technology, Japan) as described previously [24].

\section{$\mathrm{Spi}^{-}$mutation assay}

The $\mathrm{Spi}^{-}$mutation assay was performed as described previously [24]. The rescued phages were used to infect E. coli XL1-Blue MRA (P2) cells. The infected cells were mixed with molten soft agar, poured on lambdatrypticase agar plates, and incubated at $37^{\circ} \mathrm{C}$. The $\mathrm{Spi}^{-}$ candidate plaques detected on the plates were suspended in $50 \mu \mathrm{L}$ of SM buffer. The suspension was spotted on the plate where the XL1-Blue MRA (P2) cells were 
spread. The plates were incubated at $37^{\circ} \mathrm{C}$; the mutants that produced clear spots were counted as confirmed $\mathrm{Spi}^{-}$mutants. The rescued phages were also used to infect $E$. coli XL1-Blue MRA cells to determine the number of rescued phages. The $\mathrm{Spi}^{-} \mathrm{MF}$ was calculated as described previously [24]. Phage lysates of the $\mathrm{Spi}^{-} \mathrm{mu}-$ tants were used as templates for PCR analysis. The PCR primers were:

primer 001 (5'-CTCTCCTTTGATGCGAATGCCAG C-3'),

primer $002\left(5^{\prime}\right.$-GGAGTAATTATGCGGAACAGAAT

CATGC-3'),

primer 005 (5'-CGTGGTCTGAGTGTGTTACAGAG G-3'),

primer $006\left(5^{\prime}\right.$-GTTATGCGTTGTTCCATACAACC

TCC-3') and.

primer 012 (5'-CGGTCGAGGGACCTAATAACTTC G-3').

The appropriate primers for DNA sequencing were selected based on the results of PCR analysis. The sequencing primers have been described previously [34-36]. The entire sequence of lambda EG10 is available at http://www.nihs.go.jp/dgm/dgm3/eg10v20.txt. DNA sequencing was performed with BigDye ${ }^{\mathrm{Tm}}$ Terminator Cycle Sequencing Kit (Applied Biosystems, Foster City, CA) and ABI PRISM ${ }^{\text {тм }} 310$ Genetic Analyzer (Applied Biosystems).

\section{Statistical analysis}

All data were expressed as mean \pm standard deviation (SD). A Tukey-test was used to determine if the differences between two groups were statistically significant. A $P$ value of $<0.05$ was considered statistically significant.

\section{Results}

Spi ${ }^{-}$MFs in the brain and spleen of X-ray-irradiated mice WT and scid mice were exposed to X-ray irradiation at a dose of $10 \mathrm{~Gy}$ and $\mathrm{Spi}^{-}$MFs were determined in the brain and spleen (Fig. 1, Supplementary Table 1 and 2). X-ray irradiation significantly enhanced $\mathrm{Spi}^{-} \mathrm{MFs}$ in both organs in WT and scid mice. The MFs in the brain of scid mice were significantly lower than those of WT mice, i.e., $2.9 \pm 1.0 \times 10^{-6}$ versus $5.0 \pm 1.1 \times 10^{-6}, P<$ 0.001 . In the spleen, however, both mouse strains exhibited similar MFs after irradiation $\left(4.1 \pm 1.8 \times 10^{-6}\right.$ vs $\left.4.8 \pm 1.4 \times 10^{-6}, P=0.77\right)$. Unirradiated scid and WT mice did not exhibit significant differences in MFs in either organ $\left(0.85 \pm 0.67 \times 10^{-6}\right.$ vs $1.0 \pm 0.64 \times 10^{-6}$ in the brain and $1.4 \pm 0.31 \times 10^{-6}$ vs $2.6 \pm 1.3 \times 10^{-6}$ in the spleen).

\section{Deletion mutation spectra in the brain of WT and scid mice}

Since MFs in the brain were significantly lower in scid mice than in WT mice, we were interested in whether the spectra of deletions were different in the two strains of mice. Therefore, we sequenced the $\mathrm{Spi}^{-}$mutants recovered from the brain of X-ray-irradiated and unirradiated WT and scid mice (Tables 1 and 2). The specific MFs of each type of deletion were calculated by multiplying the MF by the ratio of the number of each class of mutations to the total number of deletion mutations.

In WT mice, the frequency of 1 base pair (bp)-deletions increased 3.0 -fold by irradiation ( 0.82 to $2.50 \times$ $\left.10^{-6}\right)$, while the frequency of deletions of more than 2 bps in size, increased 20.3-fold (0.12 to $\left.2.43 \times 10^{-6}\right)$. Among the sequenced 35 deletions of more than $2 \mathrm{bps}$ in size, $37 \%(13 / 35)$ were deletions of more than $1 \mathrm{~kb}$ and $60 \%(21 / 35)$ had microhomologous sequences of 1

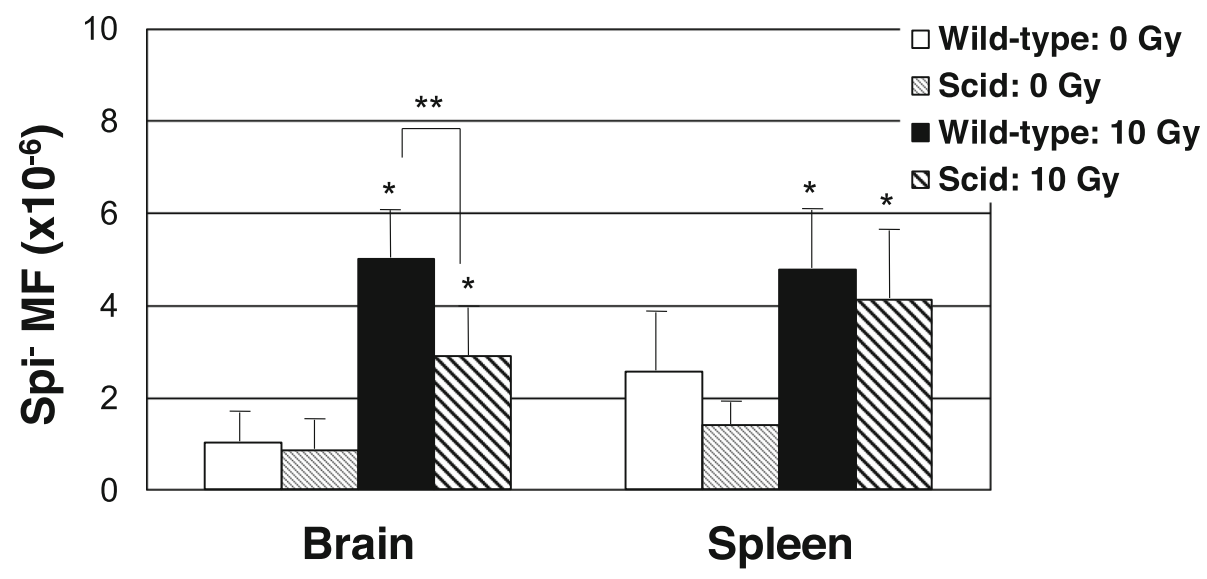

Fig. 1 The Spi ${ }^{-}$MFs in the brain and the spleen of WT and sicd mice with or without X-ray-irradiation. Error bars mean \pm SD of the MFs in each group; $n=10$ for WT (0 Gy), $n=8$ for WT (10 Gy), $n=6$ for scid (0 Gy) and $n=7$ for scid (10 Gy). * $p<0.01$, relative to the unirradiated groups. ** $P<0.01$, relative to the WT mice. A Tukey-test was used to determine if the differences between two groups were statistically significant 
Table $1 \mathrm{Spi}^{-}$mutation spectra in the brain of X-ray-irradiated WT and the scid mice

\begin{tabular}{|c|c|c|c|c|c|c|c|c|c|c|c|c|}
\hline & \multicolumn{3}{|c|}{ WT O Gy } & \multicolumn{3}{|c|}{ WT $10 \mathrm{~Gy}$} & \multicolumn{3}{|c|}{ scid O Gy } & \multicolumn{3}{|c|}{ scid $10 \mathrm{~Gy}$} \\
\hline & $\overline{\text { No. }}$ & $\%$ & $\mathrm{MFx} 10^{-6}$ & No. & $\%$ & $M F \times 10^{-6}$ & No. & $\%$ & $\mathrm{MF} \times 10^{-6}$ & No. & $\%$ & $\mathrm{MF} \times 10^{-6}$ \\
\hline \multicolumn{13}{|l|}{1 bp deletion } \\
\hline In run & 18 & 72 & 0.74 & 30 & 42 & 2.08 & 6 & 75 & 0.64 & 40 & 42 & 1.22 \\
\hline Other & 2 & 8 & 0.08 & 6 & 8 & 0.42 & 0 & 0 & 0.00 & 10 & 11 & 0.30 \\
\hline \multicolumn{13}{|l|}{$>2$ bp deletion } \\
\hline With microhomology & 0 & 0 & 0.00 & 21 & 29 & 1.46 & 0 & 0 & 0.00 & 25 & 26 & 0.76 \\
\hline Without microhomology & 3 & 12 & 0.12 & 12 & 17 & 0.83 & 1 & 13 & 0.11 & 11 & 12 & 0.33 \\
\hline Insertion & 0 & 0 & 0.00 & 2 & 3 & 0.14 & 0 & 0 & 0.00 & 4 & 4 & 0.12 \\
\hline Insertion & 2 & 8 & 0.08 & 0 & 0 & 0.00 & 0 & 0 & 0.00 & 5 & 5 & 0.15 \\
\hline Complex & 0 & 0 & 0.00 & 1 & 1 & 0.07 & 1 & 13 & 0.11 & 0 & 0 & 0.00 \\
\hline Total & 25 & 100 & 1.03 & 72 & 100 & 5.00 & 8 & 100 & 0.85 & 95 & 100 & 2.89 \\
\hline
\end{tabular}

Specific MFs were calculated by multiplying the total MF by the ratio of each class of mutants

In unirradiated WT mice, total 26 mutants (suppl. Table 1) were obtained. They were sequenced and 25 deletion mutations (Table 1 ) were identified. In 10 Gyirradiated WT mice, total 172 mutants were obtained. Eighty seven mutants were sequenced and 72 deletion mutations were identified. In unirradiated scid mice, total 9 mutants were obtained. All were sequenced and 8 deletion mutations were identified. In 10 Gy-irradiated scid mice, total $67+89$ mutants were obtained. One hundred and twenty five were sequenced and 95 deletion mutations were identified. In 10 Gy-irradiated scid mice, 89 mutants were obtained by additional plating for sequencing analysis, but they were not used for calculation of MF because no additional plating was conducted for control groups

to $4 \mathrm{bps}$ at the junction. The average length of microhomology was $1.8 \mathrm{bp}$. Six \% (2/35) had an inserted base at the junctions.

In scid mice, the frequency of $1 \mathrm{bp}$-deletions increased 2.4 -fold by irradiation $\left(0.64\right.$ to $\left.1.52 \times 10^{-6}\right)$, while the frequency of deletions of more than $2 \mathrm{bps}$ in size, increased 11.1 -fold $\left(0.11\right.$ to $\left.1.22 \times 10^{-6}\right)$. Among the sequenced 40 deletions of more than $2 \mathrm{bps}$ in size, $35 \%$ $(14 / 40)$ were more than $1 \mathrm{~kb}$ and $63 \%$ (25/40) had microhomologous sequences at the junction. With the exception of one mutation that had a 12-bp microhomology, the average length of microhomology was 1.7 bp. Five mutations containing a $1 \mathrm{bp}$-insertion, not accompanied by deletions, were observed in irradiated scid mice, whereas no such mutations were observed in irradiated WT mice.

There was no significant difference in the mutation spectra between unirradiated WT and scid mice. One bp-deletions in the repetitive sequences were the most dominant type of mutation. Three hotspots were observed in unirradiated mice: 1) AAAAA to AAAA at position 227-231, 2) GGGG to GGG at position 286289 and 3) AAAAAA to AAAAA at position 295-300 in the gam gene.

\section{Discussion}

Although it is well known that the scid mice are severely sensitive to killing effects of irradiation, little is known about the roles of DNA PKcs in irradiation-induced deletion mutations in various organs of mice. In this study, the WT and scid mice were irradiated with X-rays and deletion mutations were analyzed in the brain and the spleen. In the X-ray-irradiated WT mice, the $\mathrm{Spi}^{-} \mathrm{MFs}$ in the brain and spleen were significantly higher than those of unirradiated mice. Sequencing analysis of the $\mathrm{Spi}^{-}$mutants in the brain showed that X-ray irradiation preferentially induced large deletions of up to $10 \mathrm{kbps}$ (Table 1). Specific MFs of deletions of more than $2 \mathrm{bps}$ in size increased 20.3-fold upon irradiation, in contrast to the MFs of deletions of $1 \mathrm{bp}$ that increased 3.0-fold. Among the sequenced 35 deletions of more than 2 bps in size, $60 \%(21 / 35)$ had microhomologous sequences of $1-4 \mathrm{bps}$ at the deleted junction (Table 2). These data confirmed that deletions of more than $2 \mathrm{bps}$ in size in this study are largely generated through NHEJ of DNA DSBs [3, 29].

In irradiated scid mice, the $\mathrm{Spi}^{-}$MFs were significantly increased 3.2- and 2.9-fold in the brain and spleen, respectively, compared with those of unirradiated scid mice. In the brain, the specific MF of deletions of more than 2 bps in size increased 11-fold by irradiation, in contrast to the MF of $1 \mathrm{bp}$-deletions that increased 1.9fold (Table 1). Sequencing analysis of the $\mathrm{Spi}^{-}$mutants showed that $63 \%(25 / 40)$ of the deletions of more than 2 bps in size had microhomologous sequences of 1-12 bps at the deleted junction. These characteristics of the $\mathrm{X}$-ray- induced deletions in scid mice were similar to those of WT mice, suggesting that X-ray-induced DSBs are repaired by NHEJ even without DNA-PKcs. It is possible, however, that the defective protein encoded by the murine scid allele retains enough residual function to support NHEJ. Bogue et al. examined V(D)J recombination in DNA-PKcs-deficient SLIP mice and found that the effects of this mutation on coding and signal joint formation are identical to the effects of the scid mutation [18]. These data are incompatible with the notion 
Table 2 Summary of Spi ${ }^{-}$mutations in the brain of X-ray-irradiated WT and scid mice

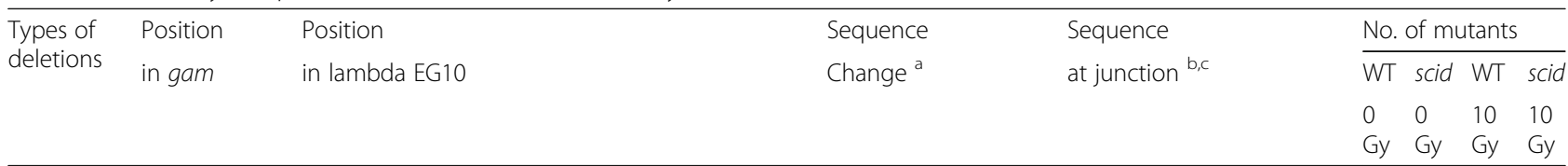

One base pair deletions

In run sequences

$141-142$
$188-190$
$199-201$
$227-231$
$238-241$
$286-289$
$290-291$
$295-300$
$316-318$
$334-336$
$377-378$
$380-381$
$387-388$
$390-391$

$\mathrm{GG} \rightarrow \mathrm{G}$

$\mathrm{CCC} \rightarrow \mathrm{CC}$

$\mathrm{AAA} \rightarrow \mathrm{AA}$

AAAAA $\rightarrow$ AAAA

$\mathrm{CCCC} \rightarrow \mathrm{CCC}$

$\mathrm{GGGG} \rightarrow \mathrm{GGG}$

$\mathrm{CC} \rightarrow \mathrm{C}$

AAAAAA $\rightarrow$ AAAAA

$\Pi T \rightarrow \Pi$

$\Pi \pi \rightarrow \pi$

$\mathrm{CC} \rightarrow \mathrm{C}$

$\Pi \rightarrow T$

$\mathrm{CC} \rightarrow \mathrm{C}$

$\mathrm{CC} \rightarrow \mathrm{C}$

$$
\begin{aligned}
& \mathrm{ttAtt} \rightarrow \mathrm{tttt} \\
& \text { cacTac } \rightarrow \text { cacac } \\
& \text { caGct } \rightarrow \text { cact } \\
& \text { gAgg } \rightarrow \text { ggg } \\
& \text { agAcg } \rightarrow \text { agcg } \\
& \mathrm{ccTgc} \rightarrow \mathrm{ccgc} \\
& \text { tcGat } \rightarrow \text { tcat } \\
& \mathrm{tttG} \rightarrow \mathrm{ttt} \\
& \text { ttgCaac } \rightarrow \text { ttgaac } \\
& \text { Cgggg } \rightarrow \text { gggg } \\
& \text { Caаaаaа } \rightarrow \text { aаaаaа } \\
& \text { aaaaaa } \rightarrow \text { aaaaaa } \\
& \mathrm{tttgAt} \rightarrow \mathrm{tttgt} \\
& \mathrm{tG} t \mathrm{tt} \rightarrow \mathrm{tt} \\
& g A g \rightarrow g g \\
& g g A g \rightarrow g g g \\
& \text { ccAgg } \rightarrow \text { ccgg }
\end{aligned}
$$

Other 1 bp deletion

$$
392
$$

$>2 \mathrm{bp}$

deletions

Deleted sizes (bp)

$$
\begin{array}{ll}
2 & 153 \rightarrow 156 \\
2 & 251 \rightarrow 254 \\
2 & 349 \rightarrow 352 \\
3 & 355 \rightarrow 359 \\
4 & 182-184 \rightarrow
\end{array}
$$

$$
\begin{aligned}
& \text { tgag tcag } \\
& \text { tgtt aatc } \\
& \text { atgg gaac } \\
& \text { gaac tccg } \\
& \text { agcaGC.ccgt }
\end{aligned}
$$


Table 2 Summary of Spi ${ }^{-}$mutations in the brain of X-ray-irradiated WT and scid mice (Continued)

\begin{tabular}{|c|c|c|c|c|c|c|c|c|}
\hline \multirow{3}{*}{$\begin{array}{l}\text { Types of } \\
\text { deletions }\end{array}$} & \multirow{3}{*}{$\begin{array}{l}\text { Position } \\
\text { in gam }\end{array}$} & \multirow{3}{*}{$\begin{array}{l}\text { Position } \\
\text { in lambda EG10 }\end{array}$} & \multirow{3}{*}{$\begin{array}{l}\text { Sequence } \\
\text { Change }^{a}\end{array}$} & \multirow{3}{*}{$\begin{array}{l}\text { Sequence } \\
\text { at junction b,c }\end{array}$} & \multicolumn{4}{|c|}{ No. of mutants } \\
\hline & & & & & $\overline{\mathrm{WT}}$ & scid & WT & $\overline{\text { scid }}$ \\
\hline & & & & & $\begin{array}{l}0 \\
\text { Gy }\end{array}$ & $\begin{array}{l}0 \\
\text { Gy }\end{array}$ & $\begin{array}{l}10 \\
\text { Gy }\end{array}$ & $\begin{array}{l}10 \\
\text { Gy }\end{array}$ \\
\hline & 187-189 & & & & & & & \\
\hline 4 & $222 \rightarrow 227$ & & & cgac aaaa & & & & 1 \\
\hline 4 & $\begin{array}{l}239-240 \rightarrow \\
244-245\end{array}$ & & & $\operatorname{tgcc} \underline{\mathbf{C}}$ acct & & & & 1 \\
\hline 4 & $\begin{array}{l}247-249 \rightarrow \\
251-253\end{array}$ & & & caccㅁgaat & & & 1 & \\
\hline 4 & 295-300 & & & cagc소tcca & & & & 1 \\
\hline 4 & $304 \rightarrow 309$ & & & tcca ccgt & & & & 1 \\
\hline 5 & $\begin{array}{l}300-301 \rightarrow \\
306-307\end{array}$ & & & aaaaIaccc & & & & 2 \\
\hline 7 & $\begin{array}{l}147-149 \rightarrow \\
155-157\end{array} \rightarrow$ & & & tcgt드caga & & & & 1 \\
\hline 7 & $\begin{array}{l}349-351 \rightarrow \\
357-359\end{array} \rightarrow$ & & & atgg $\underline{\text { A Atccg }}$ & & & 1 & \\
\hline 8 & $175 \rightarrow 184$ & & & cact ctcg & & & 1 & \\
\hline 10 & $\begin{array}{l}196-198 \rightarrow \\
207-209\end{array}$ & & & gaag $\underline{\text { AGaact }}$ & & & 1 & \\
\hline 10 & $323 \rightarrow 334$ & & & atga tttc & & & 1 & \\
\hline 10 & $335 \rightarrow 346$ & & & agtt atgg & & & 1 & \\
\hline 10 & $\begin{array}{l}375-379 \rightarrow \\
386-390\end{array}$ & & & $\operatorname{tgaaAC} \underline{\mathbf{A C}} \mathrm{cacc}$ & & & 1 & \\
\hline 12 & $\begin{array}{l}221-222 \rightarrow \\
234-235\end{array}$ & & & $\operatorname{acga} \underline{\mathbf{C}} \operatorname{ctg} \mathrm{c}$ & & & & 1 \\
\hline 12 & $313 \rightarrow 326$ & & & cgtg atgt & & & 1 & \\
\hline 13 & $\begin{array}{l}376-379 \rightarrow \\
389-392\end{array}$ & & & gaaaCCAggtt & & & 1 & \\
\hline 14 & $\begin{array}{l}165-167 \rightarrow \\
180-182\end{array} \rightarrow$ & & & ctgg $\underline{\mathbf{G}}$ cagc & & & 1 & \\
\hline 17 & $\begin{array}{l}154-155 \rightarrow \\
172-173\end{array}$ & & & gagg $\underline{\text { Cacta }}$ & & & 1 & \\
\hline 17 & $\begin{array}{l}239-240 \rightarrow \\
257-258\end{array}$ & & & $\operatorname{ctg} c \underline{C}$ gcta & & & & 1 \\
\hline 17 & $251 \rightarrow 269$ & & & tgtt atca & & & & 1 \\
\hline 19 & $\begin{array}{l}212-215 \rightarrow \\
232-235\end{array} \rightarrow$ & & & aactGGCctgc & & & & 1 \\
\hline 22 & $\begin{array}{l}288-289 \rightarrow \\
311-312\end{array}$ & & & 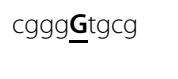 & & & & 3 \\
\hline 26 & $268 \rightarrow 285$ & & & atcg cggg & & & & $2^{d}$ \\
\hline 28 & $307 \rightarrow 336$ & & & atta tcag & & & 1 & \\
\hline 28 & $338 \rightarrow 367$ & & & ttca atgg & & 1 & & \\
\hline 32 & $\begin{array}{l}189-190 \rightarrow \\
222-223\end{array} \rightarrow$ & & & cgccㅡatgg & & & 1 & \\
\hline 34 & $\begin{array}{l}346-348 \rightarrow \\
381-383\end{array}$ & & & cgca $\underline{\mathbf{T G}}$ ctca & & & 1 & \\
\hline 41 & $380 \rightarrow 422$ & & & ccat aatg & & & & 1 \\
\hline 49 & $\begin{array}{l}206 \rightarrow 257 \\
(1 \text { bp ins.) }\end{array}$ & & & $\operatorname{aggc} \boldsymbol{C}$ cgct & & & 1 & \\
\hline 67 & $246-247 \rightarrow$ & & & gcacㄷgttt & & & & 1 \\
\hline
\end{tabular}


Table 2 Summary of Spi ${ }^{-}$mutations in the brain of X-ray-irradiated WT and scid mice (Continued)

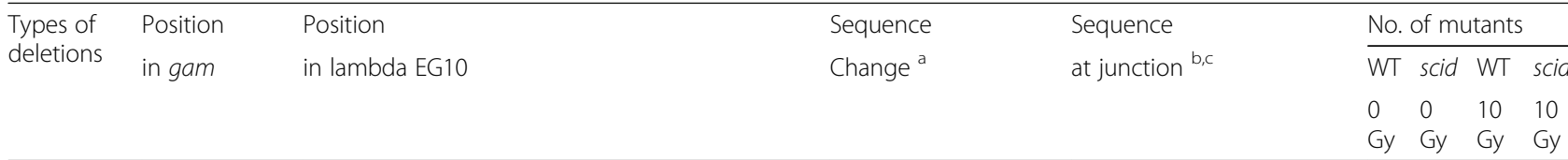

\begin{tabular}{cl}
\hline & $314-315$ \\
76 & $189 \rightarrow 266$ \\
86 & $252-253 \rightarrow$ \\
& $339-340$ \\
107 & $91-92 \rightarrow$ \\
& $199-200$ \\
124 & $208 \rightarrow 333$ \\
127 & $273-276 \rightarrow$ \\
& $401-404$
\end{tabular}

151

432

449

596

654

1248

1436

1557

1616

1856

1874

2124

2388

2388

2441

2842

3628

3701

3707

3979

4144

4689

4698

4841

5037

5251

5422

5562

5727

6900

7303

9030
$24,867-24,870 \rightarrow 25,019-25,022$

$24,828-24,830 \rightarrow 25,261-25,263$

$24,683-24,684 \rightarrow 25,133-25,134$

$24,446-24,450 \rightarrow 25,043-25,047$

$24,719 \rightarrow 25,374$

$24,524-24,536 \rightarrow 25,767-25,779$

$24,563 \rightarrow 26,000$

$24,222 \rightarrow 25,802$ (22 bps ins.)

23,938-25,555 (2 bps ins.)

$23,960-23,961 \rightarrow 25,817-25,818$

$24,161-24,162 \rightarrow 26,009-26,010$

$23,141 \rightarrow 25,266$ ( 1 bp ins.)

23,000-23,004 $\rightarrow$ 25,389-25,393

$24,000-24,002 \rightarrow 28,232-28,234$

$24,034-24,035 \rightarrow 26,476-26,477$

$24,247-24,248 \rightarrow 27,090-27,091$

$25,062 \rightarrow 28,691$

$24,560 \rightarrow 28,262$

$21,458-21,459 \rightarrow 25,166-25,167$

$22,200-22,204 \rightarrow 26,180-26,184$

$22,585-22,586 \rightarrow 26,730-26,731$

$23,611-23,612 \rightarrow 28,301-28,302$

$24,423-24,424 \rightarrow 29,122-29,123$

$21,691-21,692 \rightarrow 26,533-26,534$

$21,355 \rightarrow 26,393$

19,712-19,713 $\rightarrow$ 24,964-24,965

$22,340 \rightarrow 27,760$ (3 bps ins.)

$19,997 \rightarrow 25,560$

$19,335 \rightarrow 25,063$

$24,036 \rightarrow 30,937$

$23,917 \rightarrow 31,221$

$21,854-21,857 \rightarrow 30,885-30,888$

\begin{tabular}{|c|c|c|}
\hline cgec tcga & & 1 \\
\hline 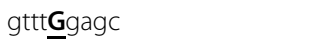 & & 1 \\
\hline cgatAaaga & & 1 \\
\hline gcag gttt & & \\
\hline tcat TTGattc & & \\
\hline cgac슴acg & & 1 \\
\hline 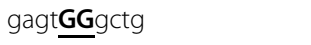 & & \\
\hline $\mathrm{ccca} \underline{\mathbf{C}} \mathrm{tttc}$ & & \\
\hline ataTGGC cccg & & \\
\hline aagg tcgc & & \\
\hline aatgGTTCGCGGCGGCgtg & & \\
\hline caga cagt & 1 & \\
\hline $\begin{array}{l}\operatorname{tgtc} C A T T C A A A A C A C A C \\
\text { CACCAAAG CtCC }\end{array}$ & & \\
\hline aaac $\boldsymbol{A} \boldsymbol{G}$ gect & & 1 \\
\hline gaag $\underline{\text { Ttggt }}$ & & 1 \\
\hline $\operatorname{tg} \underline{\operatorname{ta}} \mathbf{g c t g}$ & & 1 \\
\hline tcgg $\boldsymbol{A}$ gatt & & \\
\hline $\operatorname{tgctGCGAtag}$ & & \\
\hline ggg $\underline{\mathbf{G T}}$ gtca & & \\
\hline cggt $\underline{\mathbf{G}}$ ccag & & \\
\hline $\operatorname{agc} \mathbf{G} c c g a$ & & \\
\hline aaa ctg & & 1 \\
\hline gatg gcac & & \\
\hline att $\underline{\mathbf{G}} \mathrm{cgcc}$ & & \\
\hline ccagITTA & & 2 \\
\hline $\operatorname{cgtt} \underline{\mathbf{C}} \operatorname{tgcc}$ & & \\
\hline agtt $\underline{\mathbf{G}} \mathrm{cgcg}$ & & 1 \\
\hline gaaG $\underline{\mathbf{G}} \mathrm{gcc}$ & & \\
\hline agac스cat & & 1 \\
\hline ctct agaa & & 1 \\
\hline cacc & & 1 \\
\hline сgсc $\mathbb{T T T}$ саса & & \\
\hline atag gatt & 1 & \\
\hline tgge tgat & & 1 \\
\hline gtga gatc & & 1 \\
\hline cttc tcgt & 1 & \\
\hline gagtACGcttt & & \\
\hline
\end{tabular}


Table 2 Summary of Spi- mutations in the brain of X-ray-irradiated WT and scid mice (Continued)

\begin{tabular}{|c|c|c|c|c|c|c|c|c|}
\hline \multirow{3}{*}{$\begin{array}{l}\text { Types of } \\
\text { deletions }\end{array}$} & \multirow{3}{*}{$\begin{array}{l}\text { Position } \\
\text { in gam }\end{array}$} & \multirow{3}{*}{$\begin{array}{l}\text { Position } \\
\text { in lambda EG10 }\end{array}$} & \multirow{3}{*}{$\begin{array}{l}\text { Sequence } \\
\text { Change }^{a}\end{array}$} & \multirow{3}{*}{$\begin{array}{l}\text { Sequence } \\
\text { at junction b,c }\end{array}$} & \multicolumn{4}{|c|}{ No. of mutants } \\
\hline & & & & & $\overline{\mathrm{WT}}$ & scid & WT & $\overline{\text { scid }}$ \\
\hline & & & & & $\begin{array}{l}0 \\
\text { Gy }\end{array}$ & $\begin{array}{l}0 \\
\text { Gy }\end{array}$ & $\begin{array}{l}10 \\
\text { Gy }\end{array}$ & $\begin{array}{l}10 \\
\text { Gy }\end{array}$ \\
\hline \multicolumn{9}{|l|}{ Insertions } \\
\hline+1 & $227-231$ & & $\mathrm{AAAAA} \rightarrow \mathrm{AAAAAA}$ & & 1 & & & \\
\hline+1 & $227-231$ & & AAAAA $\rightarrow$ AAAAAA & & & & & \\
\hline+1 & $295-300$ & & AAAAAA $\rightarrow$ AAAAAAA & & & & & $4^{d}$ \\
\hline+1 & 356 & & aaca $\rightarrow$ aacTa & & 1 & & & \\
\hline \multicolumn{9}{|l|}{ Complex } \\
\hline N.D. & & $23,999 \rightarrow 24,381,23,997-23,996 \rightarrow 27,762-27,763$ & & & & 1 & & \\
\hline \multirow[t]{2}{*}{ N.D. } & & $21,108-21,109 \rightarrow 13-14$ & & & & & 1 & \\
\hline & & & & & 25 & 8 & 72 & 95 \\
\hline
\end{tabular}

\footnotetext{
${ }^{a}$ Capital letters are deleted or Inserted bases

${ }^{\mathrm{b}}$ Bold and underlined bases denote homologous sequences of deletion junctions

c Bold and italic bases denote inserted sequences at deletion junctions

d The mutations were independently observed from more than two different mice
}

that signal joint formation in scid mice results from residual DNA-PKcs function and support the idea that DNA-PKcs is not an essential factor for NHEJ in mice. The analysis of DNA-PKcs knock-out mice also supports this idea [37]. Hence, we suggest that DNA-PKcsindependent NHEJ is responsible for deletions associated with X-ray exposure in the spleen and, in part, in the brain.

How can NHEJ proceed without DNA-PKcs in the brain and spleen? DNA-PKcs interacts with the Cterminal part of Ku80, a component of DNA-PK. When $\mathrm{Ku}$ binds to DNA ends, the interaction with DNA PKcs increases substantially, which leads to autophosphorylation of DNA PKcs and activation of the endonuclease activities of Artemis [38]. This endonuclease appears to play a role in the removal of $5^{\prime}$ - and $3^{\prime}$-overhangs in DNA ends, which seems to be a necessary step for the efficient ligation of broken DNA ends. It is estimated, however, that more than half of IR-induced DSBs are repaired even without the activities of Artemis [39, 40]. This suggests that nucleases other than Artemis, such as Apratoxin and PNKP-like factor (APLF), flap endonuclease (FEN1), DNA replication helicase/nuclease 2 (DNA 2 ) and exonuclease 1 , may play roles in the resection of broken DNA with incompatible DNA ends [3]. We speculate, therefore, that DNA PKcs-independent nucleases may play roles in NHEJ in the brain and spleen while the canonical DNA PKcs-dependent Artemis is involved in NHEJ in the brain. Obviously, further work is needed to reveal exact mechanisms by which NHEJ proceeds without DNA PKcs in the organs.

Unirradiated scid and WT mice did not exhibit significant differences in MFs in the brain and spleen (Fig. 1). In addition, the spectra of deletions were similar between the two strains of mice, where $1 \mathrm{bp}$-deletions in the repetitive sequences were the most dominant. These deletions, however, are mostly generated by slippage of DNA polymerases during DNA replication and not during DNA repair of DSBs [29]. It is reported that spontaneous lacI MFs were similar between scid and WT mice in the brain, spleen and liver [41]. Spontaneous MF of expanded simple tandem repeat (ESTR) in male germline was higher in the scid mice than in the WT mice although the frequency was not enhanced by irradiation [42].

Lee et al. report that DNA-PK activity fluctuates in a cell cycle-dependent manner, and propose a model in which two illegitimate recombinational repair pathways exist in mammals, one of them being DNA-PK dependent and restricted to the G1/early S phase and the other being DNA-PK independent and restricted to the late S/G2 phase of the cell cycle [43]. They showed that the DNA DSB repair activity in the scid pre-B cells was greatly reduced during the G1/early $S$ phase resulting in increased $\mathrm{X}$-ray hypersensitivity but was indistinguishable from that in WT cells during the late $S$ and G2 phases. In the spleen, in which cell division is active, DNA-PK independent repair may work well during the late $S$ and $G 2$ phases and neutralize the effect of the scid mutation. In the brain, in which cell division is inactive, DNA-PK dependent end-joining may play an important role in DSB repair and, in this context, the scid mutation may lead to a reduced activity of DSB repair and the induction of deletion mutations. In the mutation spectra of $\mathrm{Spi}^{-}$mutations recovered from the brain of the irradiated scid mice, there were 4 mutations having insertion sequences at the deleted junctions and 5 mutations having +1 insertions. This was observed in 9.5\% (9/95) 
of the analyzed samples (Table 2). In the irradiated WT mice, there were 2 mutations having insertion sequences at the deleted junctions and no mutations having +1 insertions. This was observed in $2.8 \%(2 / 72)$ of the analyzed samples. The higher frequency of mutations with insertions that was observed in the irradiated scid mice raises the possibility that DNA-PKcs-independent NHEJ may incorporate more nucleotides compared with DNA-PKcs-dependent NHEJ during DNA DSBs repair. Other characteristics of the mutation spectra in the brain of irradiated mice were similar between scid and WT mice.

\section{Conclusions}

$\mathrm{X}$-ray-induced deletions are predominantly generated by NHEJ in the brain and spleen of irradiated mice. NHEJ proceeds in DNA-PKcs-dependent and DNA PKcs-independent manners. DNA-PKcs contributes to NHEJ in the brain while it is dispensable in the spleen. This study suggests the organ specificity of the roles of DNA PKCs in deletion induction and raises a question of how NHEJ proceeds in the absence of DNA PKcs in mammalian organs.

\section{Supplementary information}

Supplementary information accompanies this paper at https://doi.org/10 1186/s41021-020-00158-y.

Additional file 1: Table S1. Spi ${ }^{-}$mutant frequency in the brain of $X$ ray-irradiated mice. Table $\mathbf{S 2}$. Spi ${ }^{-}$mutant frequency in the spleen of $\mathbf{X}$ ray-irradiated mice.

\section{Abbreviations}

DNA-PK: DNA-dependent protein kinase; DNA PKcs: The catalytic subunit of DNA PK; scid: Severe combined immunodeficient; WT: Wild type;

MFs: Mutant frequencies; NHEJ: Non-homologous end-joining; DSBs: Doublestrand breaks; IR: Ionizing radiation; Spi: Sensitive to P2 interference; SD: Standard deviation; bp: Base pair; APLF: Apratoxin and PNKP-like factor; FEN1: Flap endonuclease: DNA 2: DNA replication helicase/nuclease 2; ESTR: Expanded simple tandem repeat

\section{Acknowledgements}

We acknowledge Ms. Makiko Hoshino, Showa Pharmaceutical University, for technical assistance for mutant analyses. We thank Drs. Otoya Ueda and Hiroshi Suzuki, Exploratory Research Laboratory, Fuji Gotemba Research Laboratory, Chugai Pharmaceutical Co., Ltd., for generation of the scid/gpt delta mice.

\section{Authors' contributions}

MK and TN designed the experiments and MK conducted most of the experiments. FY irradiated the mice with $\mathrm{X}$-ray and MO and $\mathrm{HN}$ characterized the scid mice. TN wrote the draft and all the authors confirmed the final manuscript.

\section{Funding}

This study was financially supported by the budget for Nuclear Research of the Ministry of Education, Culture, Sports, Science and Technology, Japan, based on the screening and counselling by the Atomic Energy Commission. This work was also supported by the Japan Health Science Foundation and the Tsuchikawa Memorial Fund for Study in Mammalian Mutagenicity.

\section{Availability of data and materials}

All data generated or analysed during this study are included in this published article and its Supplementary Table 1 and 2.

\section{Ethics approval and consent to participate}

All animal care and experimental procedures were conducted in compliance with the internal regulation for animal use at the National Institute of Health Sciences.

\section{Consent for publication}

Not applicable.

\section{Competing interests}

The authors declare that they have no competing interests.

\section{Author details}

'Division of Genetics and Mutagenesis, National Institute of Health Sciences, 3-25-26 Tonomachi, Kawasaki-ku, Kawasaki-shi, Kanagawa 210-9501, Japan.

${ }^{2}$ Center for Sustainable Resource Science, The Institute of Physical and Chemical Research, 2-1 Hirosawa, Wako-shi, Saitama 351-0198, Japan. ${ }^{3}$ Biochemistry Division, National Cancer Center Research Institute, 5-1-1 Tsukiji, Chuo-ku, Tokyo 104-0045, Japan. ${ }^{4}$ Present Address: Department of Animal Experimentation, National Cancer Center Research Institute, 5-1-1 Tsukiji, Chuo-ku, Tokyo 104-0045, Japan. ${ }^{5}$ Present Address: National Cancer Center, 5-1-1 Tsukiji, Chuo-ku, Tokyo 104-0045, Japan.

Received: 7 February 2020 Accepted: 16 May 2020

Published online: 24 May 2020

\section{References}

1. Jackson SP. Sensing and repairing DNA double-strand breaks. Carcinogenesis. 2002;23(5):687-96.

2. Takata M, Sasaki MS, Sonoda E, Morrison C, Hashimoto M, Utsumi H, et al. Homologous recombination and non-homologous end-joining pathways of DNA double-strand break repair have overlapping roles in the maintenance of chromosomal integrity in vertebrate cells. EMBO J. 1998;17(18):5497-508.

3. Pannunzio NR, Watanabe G, Lieber MR. Nonhomologous DNA end-joining for repair of DNA double-strand breaks. J Biol Chem. 2018;293(27):10512-23.

4. Seol JH, Shim EY, Lee SE. Microhomology-mediated end joining: good, bad and ugly. Mutat Res. 2018;809:81-7.

5. Jeggo PA, Taccioli GE, Jackson SP. Menage a trois: double strand break repair, V(D)J recombination and DNA-PK. Bioessays. 1995;17(11):949-57.

6. Hefferin ML, Tomkinson AE. Mechanism of DNA double-strand break repair by non-homologous end joining. DNA Repair (Amst). 2005;4(6):639-48.

7. Smith GC, Jackson SP. The DNA-dependent protein kinase. Genes Dev. 1999; 13(8):916-34.

8. Collis SJ, DeWeese TL, Jeggo PA, Parker AR. The life and death of DNA-PK. Oncogene. 2005:24(6):949-61.

9. Davis AJ, Chen BP, Chen DJ. DNA-PK: a dynamic enzyme in a versatile DSB repair pathway. DNA Repair (Amst). 2014;17:21-9.

10. Chang HH, Watanabe $G$, Gerodimos $C A$, Ochi $T$, Blundell $T L$, Jackson SP, et al. Different DNA end configurations dictate which NHEJ components are most important for joining efficiency. J Biol Chem. 2016;291(47):24377-89.

11. Kirchgessner CU, Patil CK, Evans JW, Cuomo CA, Fried LM, Carter T, et al. DNA-dependent kinase (p350) as a candidate gene for the murine SCID defect. Science. 1995;267(5201):1178-83.

12. Finnie NJ, Gottlieb TM, Blunt T, Jeggo PA, Jackson SP. DNA-dependent protein kinase activity is absent in xrs- 6 cells: implications for site-specific recombination and DNA double-strand break repair. Proc Natl Acad Sci U S A. 1995;92(1):320-4.

13. Blunt T, Gell D, Fox M, Taccioli GE, Lehmann AR, Jackson SP, et al. Identification of a nonsense mutation in the carboxyl-terminal region of DNA-dependent protein kinase catalytic subunit in the scid mouse. Proc Natl Acad Sci U S A. 1996:93(19):10285-90.

14. Araki R, Fujimori A, Hamatani K, Mita K, Saito T, Mori M, et al. Nonsense mutation at Tyr-4046 in the DNA-dependent protein kinase catalytic subunit of severe combined immune deficiency mice. Proc Natl Acad Sci U S A. 1997:94(6):2438-43.

15. Biedermann KA, Sun JR, Giaccia AJ, Tosto LM, Brown JM. scid mutation in mice confers hypersensitivity to ionizing radiation and a deficiency in DNA double-strand break repair. Proc Natl Acad Sci U S A. 1991;88(4):1394-7. 
16. Schuler W, Weiler IJ, Schuler A, Phillips RA, Rosenberg N, Mak TW, et al. Rearrangement of antigen receptor genes is defective in mice with severe combined immune deficiency. Cell. 1986;46(7):963-72.

17. Bosma MJ, Carroll AM. The SCID mouse mutant: definition, characterization, and potential uses. Annu Rev Immunol. 1991;9:323-50.

18. Bogue MA, Jhappan C, Roth DB. Analysis of variable (diversity) joining recombination in DNAdependent protein kinase (DNA-PK)-deficient mice reveals DNA-PK-independent pathways for both signal and coding joint formation. Proc Natl Acad Sci U S A. 1998;95(26):15559-64.

19. Nussenzweig A, Chen C, da Costa Soares V, Sanchez M, Sokol K, Nussenzweig MC, et al. Requirement for Ku80 in growth and immunoglobulin V(D)J recombination. Nature. 1996;382(6591):551-5.

20. Zhu C, Bogue MA, Lim DS, Hasty P, Roth DB. Ku86-deficient mice exhibit severe combined immunodeficiency and defective processing of $V(D) J$ recombination intermediates. Cell. 1996;86(3):379-89.

21. Gu Y, Seidl KJ, Rathbun GA, Zhu C, Manis JP, van der Stoep N, et al. Growth retardation and leaky SCID phenotype of Ku70-deficient mice. Immunity. 1997;7(5):653-65.

22. Li GC, Ouyang H, Li X, Nagasawa H, Little JB, Chen DJ, et al. Ku70: a candidate tumor suppressor gene for murine T cell lymphoma. Mol Cell. 1998:2(1):1-8.

23. Nohmi T, Katoh M, Suzuki H, Matsui M, Yamada M, Watanabe M, et al. A new transgenic mouse mutagenesis test system using Spi ${ }^{-}$and 6thioguanine selections. Environ Mol Mutagen. 1996;28(4):465-70.

24. Nohmi T, Suzuki T, Masumura K. Recent advances in the protocols of transgenic mouse mutation assays. Mutat Res. 2000;455(1-2):191-215.

25. Aoki Y, Nakajima D, Matsumoto M, Yagishita M, Matsumoto M, Yanagisawa $R$, et al. Change over time of the mutagenicity in the lungs of gpt delta transgenic mice by extract of airborne particles collected from ambient air in the Tokyo metropolitan area. Genes Environ. 2018;40:25.

26. Masumura K, Matsui M, Katoh M, Horiya N, Ueda O, Tanabe H, et al. Spectra of gpt mutations in ethylnitrosourea-treated and untreated transgenic mice. Environ Mol Mutagen. 1999;34(1):1-8.

27. Masumura K, Sakamoto Y, Kumita W, Honma M, Nishikawa A, Nohmi T. Genomic integration of lambda EG10 transgene in gpt delta transgenic rodents. Genes Environ. 2015:37:24

28. Nohmi T, Suzuki M, Masumura K, Yamada M, Matsui K, Ueda O, et al. Spi ${ }^{-}$ selection: an efficient method to detect gamma-ray-induced deletions in transgenic mice. Environ Mol Mutagen. 1999;34(1):9-15.

29. Nohmi T, Masumura K. Molecular nature of intrachromosomal deletions and base substitutions induced by environmental mutagens. Environ Mol Mutagen. 2005;45(2-3):150-61.

30. Ikeda H, Shimizu H, Ukita T, Kumagai M. A novel assay for illegitimate recombination in Escherichia coli: stimulation of lambda bio transducing phage formation by ultra-violet light and its independence from RecA function. Adv Biophys. 1995;31:197-208.

31. Takeiri A, Mishima M, Tanaka K, Shioda A, Ueda O, Suzuki H, et al. Molecular characterization of mitomycin C-induced large deletions and tandem-base substitutions in the bone marrow of gpt delta transgenic mice. Chem Res Toxicol. 2003;16(2):171-9.

32. Nohmi T, Masumura K. gpt delta transgenic mouse: a novel approach for molecular dissection of deletion mutations in vivo. Adv Biophys. 2004;38:97-121.

33. Busuttil RA, Munoz DP, Garcia AM, Rodier F, Kim WH, Suh Y, et al. Effect of Ku80 deficiency on mutation frequencies and spectra at a LacZ reporter locus in mouse tissues and cells. PLoS One. 2008;3(10):e3458.

34. Horiguchi M, Masumura K, Ikehata H, Ono T, Kanke Y, Nohmi T. Molecular nature of ultraviolet B light-induced deletions in the murine epidermis. Cancer Res. 2001:61(10):3913-8.

35. Yatagai F, Kurobe T, Nohmi T, Masumura K, Tsukada T, Yamaguchi H, et al. Heavy-ion-induced mutations in the gpt delta transgenic mouse: effect of p53 gene knockout. Environ Mol Mutagen. 2002;40(3):216-25.

36. Masumura K, Kuniya K, Kurobe T, Fukuoka M, Yatagai F, Nohmi T. Heavy-ioninduced mutations in the gpt delta transgenic mouse: comparison of mutation spectra induced by heavy-ion, $\mathrm{X}$-ray, and gamma-ray radiation. Environ Mol Mutagen. 2002:40(3):207-15.

37. Gao Y, Chaudhuri J, Zhu C, Davidson L, Weaver DT, Alt FW. A targeted DNAPKcs-null mutation reveals DNA-PK-independent functions for KU in V(D)J recombination. Immunity. 1998;9(3):367-76.

38. Ma Y, Pannicke U, Schwarz K, Lieber MR. Hairpin opening and overhang processing by an Artemis/DNA-dependent protein kinase complex in nonhomologous end joining and V(D)J recombination. Cell. 2002;108(6): 781-94.

39. Riballo E, Kuhne M, Rief N, Doherty A, Smith GC, Recio MJ, et al. A pathway of double-strand break rejoining dependent upon ATM, Artemis, and proteins locating to gamma-H2AX foci. Mol Cell. 2004;16(5):715-24.

40. Kurosawa A, Koyama H, Takayama S, Miki K, Ayusawa D, Fujii M, et al. The requirement of Artemis in double-strand break repair depends on the type of DNA damage. DNA Cell Biol. 2008;27(1):55-61.

41. Andrew SE, Pownall S, Fox J, Hsiao L, Hambleton J, Penney JE, et al. A novel lacl transgenic mutation-detection system and its application to establish baseline mutation frequencies in the scid mouse. Mutat Res. 1996;357(1-2):57-66.

42. Yamauchi M, Nishimura M, Tsuji S, Terada M, Sasanuma M, Shimada Y. Effect of SCID mutation on the occurrence of mouse Pc-1 (Ms6-hm) germline mutations. Mutat Res. 2002;503(1-2):43-9.

43. Lee SE, Mitchell RA, Cheng A, Hendrickson EA. Evidence for DNA-PKdependent and -independent DNA double-strand break repair pathways in mammalian cells as a function of the cell cycle. Mol Cell Biol. 1997;17(3): 1425-33.

\section{Publisher's Note}

Springer Nature remains neutral with regard to jurisdictional claims in published maps and institutional affiliations.
Ready to submit your research? Choose BMC and benefit from:

- fast, convenient online submission

- thorough peer review by experienced researchers in your field

- rapid publication on acceptance

- support for research data, including large and complex data types

- gold Open Access which fosters wider collaboration and increased citations

- maximum visibility for your research: over 100M website views per year

At BMC, research is always in progress.

Learn more biomedcentral.com/submissions 